\title{
Hypothyroidism in a Dog-A Case Report
}

\author{
S. Ramesh $^{1}$, R. Sokkalingam ${ }^{2}$, S. Subapriya ${ }^{3 *}$, C. Soundararajan ${ }^{4}$ \\ and S. Muthukrishnan ${ }^{5}$
}

\begin{abstract}
${ }^{1}$ Centralised Instrumentation Laboratory, ${ }^{4}$ Department of Veterinary Parasitology,
${ }^{3}$ Centralised Clinical Laboratory, Madras Veterinary College, Chennai-07, India

${ }^{2}$ Society for the Prevention of Cruelty to Animals (SPCA), Vepery, Chennai-07, India

${ }^{5}$ Tirunelveli Veterinary College and Research Institute, Tamil Nadu, India
\end{abstract}

*Corresponding author

\section{A B S T R A C T}

\section{Keywords}

Dogs, Alopecia, Hypothyroidism

\section{Article Info}

Accepted:

30 November 2018

Available Online:

10 December 2018
A 7 years old female Labrador dog was presented with the history of alopecia with pruritis and inappetance for the past three months. Physical examination revealed bilateral alopecia with hyperpigmentation of skin. Thyroid function tests revealed decrease in T3 and T4 and increase in TSH values and thus indicating hypothyroidism. Haematological and other biochemical parameters were found be within normal limits except leukocytosis. Based on the laboratory findings the animal was treated with Levothyroxine sodium (Eltroxin tab) (a) $20 \mu \mathrm{g} / \mathrm{kg}$ body weight PO, q 12hrs. Application of Ketoconazole (2\%) shampoo was advised twice a week for a period of 4 weeks. In addition, vitamins supplement was also advocated. The animal showed dramatic improvement after one month of treatment and complete hair regrowth was noticed after 2 months. The animal returned to euthyroid state after two months of treatment.

\section{Introduction}

Hypothyroidism is one of the most common endocrine disorders encountered in dogs (Williams et al., 1996). It occurs most commonly in 4 to 8 year old, mid- to largesized purebred dogs. Breeds commonly affected include Golden Retriever, Doberman Pinscher, Irish Setter, Miniature Schnauzer, Dachshund, Cocker Spaniel, Airdale Terrier, Boxer, Poodle, Borzoi, Beagle, Irish Setter and Old English Sheepdog (Scott-Moncrieff, 2007).
Most affected dogs have primary hypothyroidism, which may be caused by lymphocytic thyroiditis, idiopathic thyroid atrophy, or, more rarely, neoplastic destruction, resulting in loss of functional thyroid tissue and impaired thyroxine (T4) production. Secondary hypothyroidism, which is less common, is caused by reduced secretion of thyrotropin (TSH) by the pituitary gland. Tertiary hypothyroidism is caused by a deficiency of hypothalamic thyrotropinreleasing hormone (TRH), and has not been documented in dogs (McKeown, 2002). The present paper reports a case of hypothyroidism 
and successful treatment with Levothyroxine sodium in a dog.

\section{Materials and Methods}

A seven years old female Labrador dog was presented at Society of Prevention of Cruelty to Animals (SPCA) hospital, Chennai with the history of alopecia with pruritis and inappetance for the past three months also treated with ivermectin and antifungal shampoos by other veterinary physicians. A thorough physical examination was done and blood samples were collected for routine hematological ( $\mathrm{Hb}, \mathrm{PCV}$, Total erythrocyte and leukocyte count) and WBC) and biochemical estimations including liver function tests (ALT), kidney function tests (BUN and creatinine) and thyroid function tests (T3, T4 and TSH). In addition, peripheral blood smears were prepared and subjected to microscopic examination for differential leukocyte count and for presence of hemoparasites. Skin scrapings were collected and examined under microscope for presence of ectoparasites. Based on the laboratory findings, the animal was treated with Levothyroxine sodium (Eltroxin tab) @ $20 \mu \mathrm{g} / \mathrm{kg}$ body weight PO, q12 hrs. In addition, vitamins supplement was also advocated. Blood samples were also collected after two months of treatment for assessing the thyroid function status.

\section{Results and Discussion}

Physical examination revealed bilateral alopecia (Fig. 1). The animal was found to be dull and exhibited symmetrical alopecia on both sides of the body with thickening of skin and few erythematous patches.

Heamatological parameters were found to be within normal limits (Table 1) except moderate leukocytosis. Differential leukocyte count revealed neutrophilic and eosinophilic response (Table 2). Liver function tests and kidney function tests revealed no abnormalities (Table 3). However, Thyroid function tests revealed abnormal values (Table 4). A marked decrease in T3 and T4 were observed while a marked increase in TSH was noticed confirming hypothyroid state. Microscopic examination of skin impression smears revealed the presence of Malassezia organisms. A dramatic improvement was noticed after one month and the animal became active and alert with complete regrowth of hair after two months of treatment (Fig. 2).

Table.1 Haematology- complete blood count

\begin{tabular}{|l|l|}
\hline Parameters & Obtained Values \\
\hline Haemoglobin & 12 gm\% \\
\hline PCV & $42 \%$ \\
\hline RBC & 6.4 millions/cumm \\
\hline WBC & 24,000 /cumm \\
\hline
\end{tabular}

Table.2 Differential leukocyte count

\begin{tabular}{|l|l|}
\hline Cells & Obtained Values \\
\hline Neutrophils & $82 \%$ \\
\hline Lymphocytes & $8 \%$ \\
\hline Eosinophils & $8 \%$ \\
\hline Monocytes and Basophils & 0 \\
\hline
\end{tabular}


Table.3 Biochemical estimations- liver function and Kidney function tests

\begin{tabular}{|l|l|}
\hline Parameters & Obtained Values \\
\hline BUN & $22 \mathrm{mg} \%$ \\
\hline Creatinine & $0.8 \mathrm{mg} \%$ \\
\hline ALT & $56 \mathrm{IU}$ \\
\hline Total Proteins & $6.6 \mathrm{gm} \%$ \\
\hline Albumin & $3.2 \mathrm{gm} \%$ \\
\hline
\end{tabular}

Table.4 Thyroid function tests

\begin{tabular}{|l|c|c|}
\hline Parameters & $\begin{array}{c}\text { Obtained value before } \\
\text { treatment }\end{array}$ & $\begin{array}{c}\text { Obtained value post } \\
\text { treatment (after 2 months) }\end{array}$ \\
\hline T3 (Total) & $67.16 \mathrm{ng} / \mathrm{dl}$ & $94.1 \mathrm{ng} / \mathrm{dl}$ \\
\hline T4 (Total) & $1.84 \mathrm{ng} / \mathrm{dl}$ & $6.8 \mathrm{ng} / \mathrm{dl}$ \\
\hline TSH & $0.9 \mathrm{ng} / \mathrm{ml}$ & $0.4 \mathrm{ng} / \mathrm{ml}$ \\
\hline
\end{tabular}

Fig.1 Labrador-7 years - female- alopecia-hypothyroidism- before treatment

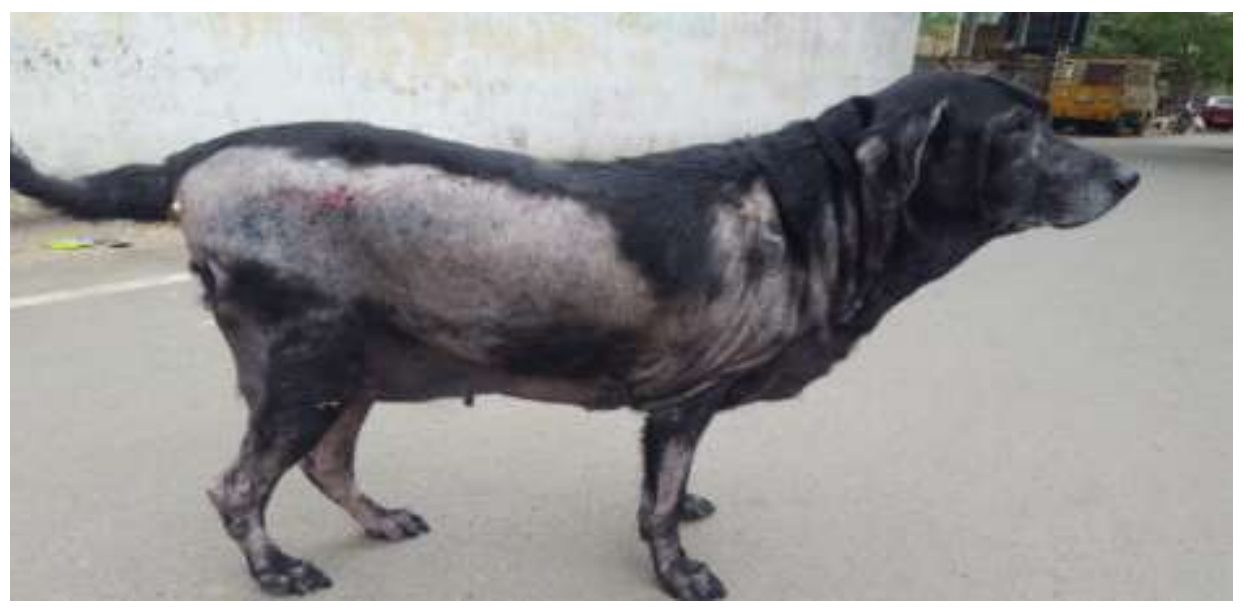

Fig.2 Labrador-7 years - female -2 months post treatment for hypothyroidism

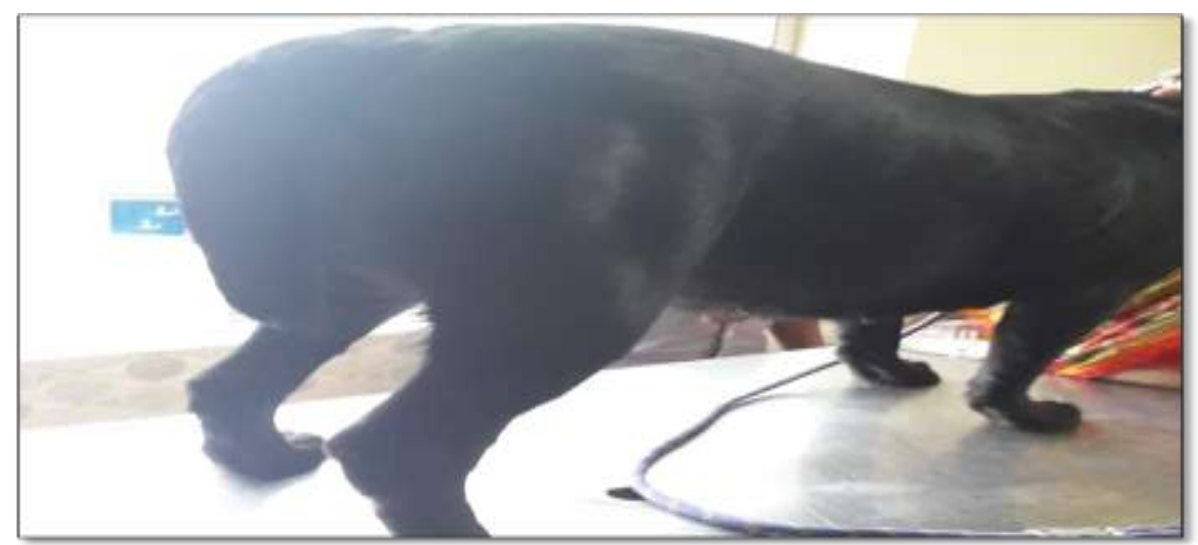


The present clinical and hematobiochemical findings were in accordance with that of Haritha et al., (2017) who recorded a decreased value of $\mathrm{T} 3$ and $\mathrm{T} 4$ and increased value of TSH in a five years old Labrador dog with alopecia associated with hypothyroidism. Dermatological changes are more commonly observed in 60-80\% hypothyroid dogs (Haritha et al., 2017). McKeown (2002) recorded hypothyroidism in six years old Boxer with neurological signs of head tilt and facial nerve paralysis which disappeared after eight weeks of treatment with Levothyroxine sodium as recorded in the present study. However neurological signs were not observed in the present study.

\section{References}

Haritha, G.S., Saritha, G and NaliniKumari, K. 2017. Malasseziosis Associated with
Hypothyroidism-A Clinical Report in a Dog. Dairy and Vet Sci J., 2(2): 1-2

McKeown, H. M. 2002 Hypothyroidism in a boxer dog. 2002. Can Vet J., 43(7): 553-555.

Scott Moncrieff, J.C. 2007. Clinical Signs and Concurrent Diseases of Hypothyroidism in Dogs and Cats. Veterinary Clinics of North America: Small Animal Practice. 37(4):709-722

Williams, D.A., Scott-Moncrieff J.C. and Bruner J., Sustarsic, D., PanosianSahakian, N. and Unver, E. 1996. Validation of an immunoassay for canine thyroid-stimulating hormone and changes in serum concentration following induction of hypothyroidism in dogs. $J$ Am Vet Med Assoc., 209(10):1730-1732

\section{How to cite this article:}

Ramesh, S., R. Sokkalingam, S. Subapriya, C. Soundararajan and Muthukrishnan, S. 2018. Hypothyroidism in a Dog- A Case Report. Int.J.Curr.Microbiol.App.Sci. 7(12): 3686-3689. doi: https://doi.org/10.20546/ijcmas.2018.712.417 